Ann. Biol. anim. Bioch. Biophys., 1978, 18 (6), 1427-1433.

\title{
Stimulation of juvenile rat ovarian adenylate cyclase by some lutropin derivatives
}

\author{
par Colette TERTRIN-CLARY, P. DE LA LLOSA
}

with the technical assistance of Marguerife ROY

Groupe de Recherche no 34, C. N.R. S., 91190 Gif sur Yveffe, France.

Summary. The stimuation of juvenile rat ovarian adenylate cyclase by several derivatives of lutropin (Luteinizing Hormone, LH) was studied. These derivatives were prepared by chemical modification of the LH lysine residues. Carbamylated LH was inactive but when the positive charge of the amino groups was preserved, the derivatives were active. The ability of the alkyl derivatives to stimulate adenylate cyclase decreased as the length of the alkyl chain increased. Only maximal activation of the ethyl and isopropyl derivatives was diminished without significant change of the concentration necessary for half-maximal stimulation $\left(A_{50}\right)$. Guanidinated LH was still active, even when 95 p. 100 of the lysine residues were modified.

Various laboratories have investigated the effects on lutropin (Luteinizing Hormone, LH) biological activity when its amino groups are chemically modified (De la Llosa et al., 1974 ; Liu et al., 1974, 1975 ; Liu and Ward, 1975 ; Sairam and Li, 1975 ; De la Llosa-Hermier et al., 1977). The bioassays used in these studies were the ovarian ascorbic acid depletion test (Parlow, 1961) and the radioligand receptor assay. It is known that the lutropin action mechanism consists of receptor binding followed by adenylate cyclase stimulation. We have shown previously (Tertrin-Clary and De la Llosa, 1975) that methylated LH, which is active in the two tests mentioned above, is also quite active when rat ovarian adenylate cyclase stimulation is studied. In this report we show how chemically modifying some lutropin lysine residues affects the ability of lutropin to stimulate ovarian adenylate cyclase in immature rat. We used these animals to investigate the enzyme-stimulating ability of lutropin derivatives, as the best ovarian adenylate cyclase response is obtained with that material (Fontaine et al., 1973 ; Mason et al., 1973 ; Mason and Marsh, 1975). The derivatives investigated were carbamyl-, guanidyl-, ethyl-, isopropyl-, benzyl- and pyridylmethyl LH. Three parameters were considered : (i) the maximal activation obtained using excess $\mathrm{LH}$ or $\mathrm{LH}$ derivative, (ii) an $\mathrm{A}_{50}$ parameter, deduced from the derivative concentration giving 50 p. 100 of maximal adenylate cyclase stimulation, and (iii) relative potencies which were defined as the quotient between the molar concentrations needed to obtain the CAMP production observed in half-maximal activation by native $\mathrm{LH}$. 


\section{Material and methods.}

Highly purified ovine LH was prepared in our laboratory with a potency of 1.89 (1.38-2.52) $\times$ NIH S11. Carbamylation and guanidination was carried out for 7 days in order to get a quantitative modification of lysine residues. Reductive alkylation (Means and Feeney, 1968) was used to introduce different alkyl chains. Acetaldehyde (Merck) was employed for ethylation, acetone for isopropylation, benzylaldehyde and isonicotinaldehyde (Sigma) for introducing benzyl and pyridylmethyl groups, respectively. All these derivatives were purified by gel filtration on Biogel P-100 as previously described (De la Llosa, 1968). Amino acid analysis (with a Technicon Autoanalyser) was used to investigate the degree of lysine residue modification. These data are summarized in table 1 . It should be pointed out that the degree of alkylation reached using different aldehydes decreases as their molecular weight and size increase.

TABLE 1

Degree of modification of derivatives

\begin{tabular}{|c|c|}
\hline Derivatives & $\begin{array}{c}\text { P. } 100 \text { of modified } \\
\text { lysine }\end{array}$ \\
\hline $\begin{array}{l}\text { Ethyl-LH } \ldots \ldots \ldots \ldots \ldots \\
\text { Propyl-LH } \ldots \ldots \ldots \ldots \ldots \\
\text { lsopropyl-LH } \ldots \ldots \ldots \ldots \\
\text { Benzyl-LH } \ldots \ldots \ldots \ldots \ldots \\
\text { Pyridylmethyl-LH } \ldots \ldots \ldots \\
\text { Guanidinated LH } \ldots \ldots \ldots \\
\text { Carbamylated LH. . . } \ldots\end{array}$ & $\begin{array}{l}66 \\
69 \\
62.5 \\
45 \\
50 \\
95 \\
50\end{array}$ \\
\hline
\end{tabular}

22-day old rats (Iffa Credo) were killed and the ovaries rapidly excised and minced. Using a loose-fitting glass homogenizer the ovaries were homogenized in

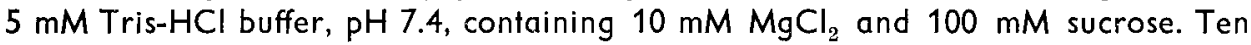
up and down strokes were given with a Teflon rod. The homogenate $(100 \mathrm{mg}$ wet tissue $/ 1 \mathrm{ml}$ buffer) was then filtered through a layer of cheese cloth. The incubation medium for adenylate cyclase assay contained $33 \mathrm{mM}$ Tris- $\mathrm{HCl}$ buffer $\mathrm{pH} 7.4,3 \mathrm{mM}$ $\mathrm{MgSO}_{4}, 2.5 \mathrm{mM} \mathrm{NaCl}, 0.1 \mathrm{mM}$ GTP, $0.1 \mathrm{mM} \mathrm{ATP}$, bovine serum albumin 0.2 p. 100, $11 \mathrm{mM}$ phosphoenol pyruvate, pyruvate kinase $80 \mu \mathrm{g} / \mathrm{ml}, 8 \mathrm{mM}$ theophylline and various amounts of hormone or derivatives. The reaction was started by adding the homogenate ( $700 \mathrm{ug}$ of protein). It was allowed to proceed for $10 \mathrm{~min}$. at $37 \mathrm{o}^{\circ} \mathrm{C}$ and stopped by addition of trichloroacetic acid to give a final concentration of 5 p. 100 . The aliquots were used for determination of CAMP accumulation after centrifugation and extraction with diethyl ether.

The amount of CAMP was ascertained by the Gilman method (Gilman, 1970) using a protein kinase prepared in the laboratory from bovine kidney. Bound and free cAMP's were separated by filtration through Millipore cellulose acetate discs. 
Radioactivity was determined with a Tricarb Packard liquid scintillation spectrometer in a solution of PPO and POPOP in toluene. The protein content was assessed by Lowry's method (Lowry ef al., 1951) using bovine serum albumin as a standard. Adenylate cyclase activity was expressed in terms of CAMP formed per $\mathrm{mg}$ of protein during a $10-\mathrm{min}$. period of incubation.

\section{Results.}

Carbamylated $\mathrm{LH}$. - Figure 1 shows the results obtained in adenylate cyclase stimulation with this derivative and with native $\mathrm{LH}$. The relative potency of the carbamylated $\mathrm{LH}$ in terms of native $\mathrm{LH}$ is about 0.01 . This very low activity is probably due to LH contamination. This confirms that positive lysine residue charges are essential for biological activity.

Guanidinated $L H$. - Figure 2 presents a comparison of the stimulation curves observed with this derivative and with native $\mathrm{LH}$. Similar curves are obtained with a guanidinated derivative containing only 75 p. 100 of modified lysine, but maximal activity is then somewhat higher $\left(70\right.$ p. 100 instead of 40 p. 100) and the $A_{50}$ is not significantly different.

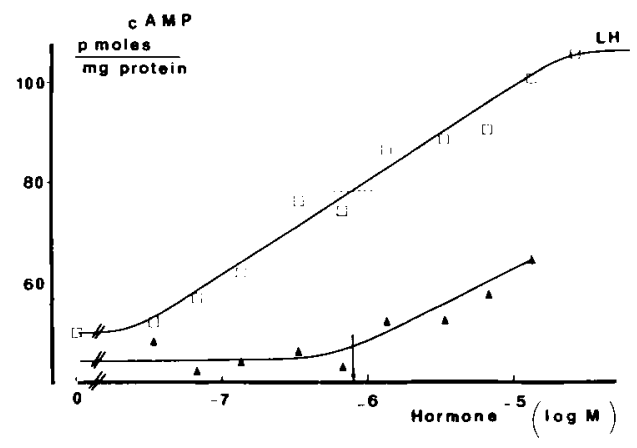

FIG. 1.

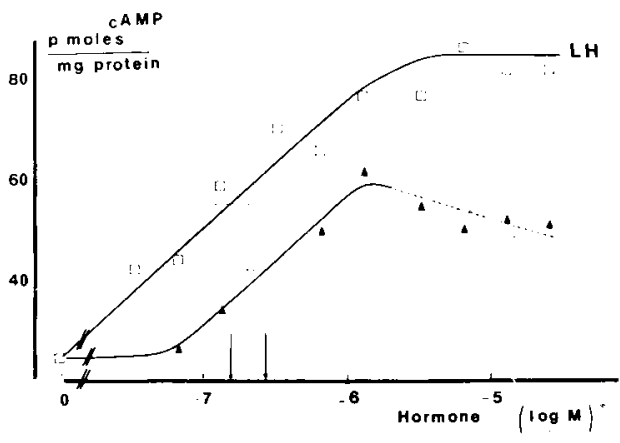

FIG. 2.

FIG. 1. - Activation of rat ovarian adenylate cyclase by lutropin and carbamylated lutropin. Adenylate cyclase activity was measured in the presence of increasing amounts of lutropin and derivative. The reaction was initiated by the addition of rat ovarian homogenate. The ordinate values indicate CAMP accumulation during a 10-min. incubation period at $37^{\circ} \mathrm{C}$. Reaction was stopped by addition of TCA. Arrows indicate $A_{50}$ values (hormonal concentration leading to half maximal activation of adenylate cyclase).

FIG. 2. - Activation of rat ovarian adenylate cyclase by $L H$ and guanidinated $L H$. Incubation was achieved in conditions similar to those of figure 1. $A_{50}$ values are $1.7 \times 10^{-7} \mathrm{M}$ and $2.7 \times 10^{-7} \mathrm{M}$, respectively.

Alkylated $\mathrm{LH}$. - Figures 3 and 4 show typical dose response curves of the alkylated derivatives. Propyl LH gives results similar to those for isopropyl LH. No significant difference is observed between the $A_{50}$ 's of ethyl and isopropyl derivatives and 
that of native LH. The maximal activation obtained with these derivatives is lower than that reached with native LH and it seems to decrease with the length of the alkyl chain.

The curves corresponding to benzyl LH (fig. 5) and pyridymethyl LH (fig. 6) are quite similar and the $A_{50}$ is higher than for native $L H$.

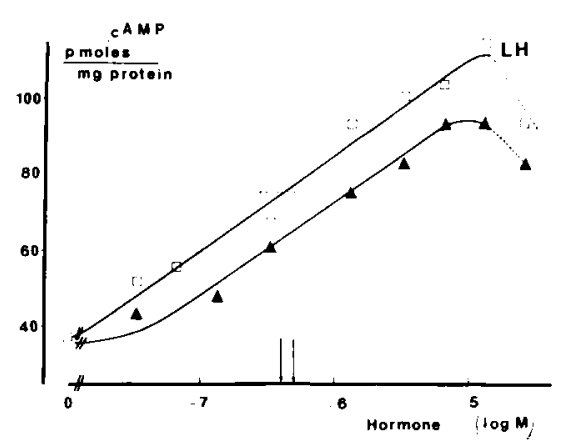

FIG. 3.

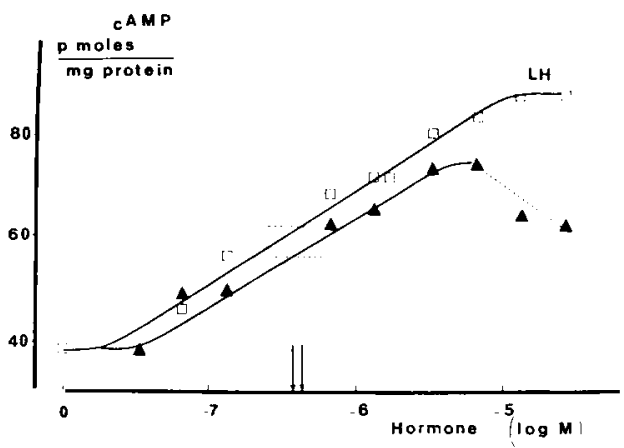

FIG. 4.

FIG. 3. - Activation of rat ovarian adenylate cyclase by $L H$ and ethylated $L H$. Incubation was achieved in conditions similar to those mentioned in figure 1. $A_{50}$ values are $4.0 \times 10^{-7} \mathrm{M}$ and $5.0 \times 10^{-7} \mathrm{M}$, respectively.

FIG. 4. - Activation of rat ovarian adenylate cyclase by $L H$ and isopropylated $L H$. Incubation was achieved in conditions similar to those of figure 1. $A_{50}$ values are $3.7 \times 10^{-7} \mathrm{M}$ and $4.3 \times 10^{-7} \mathrm{M}$, respectively.

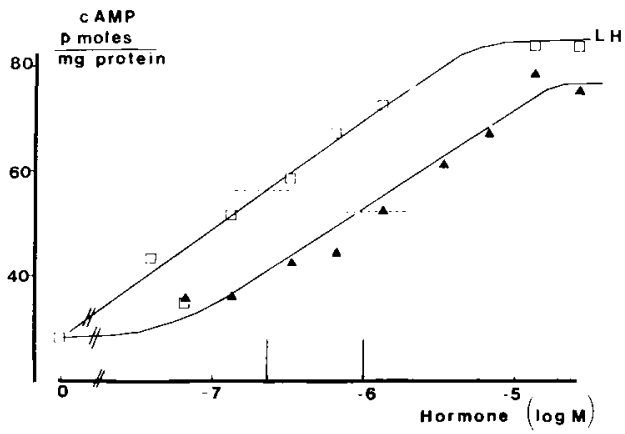

FIG. 5.

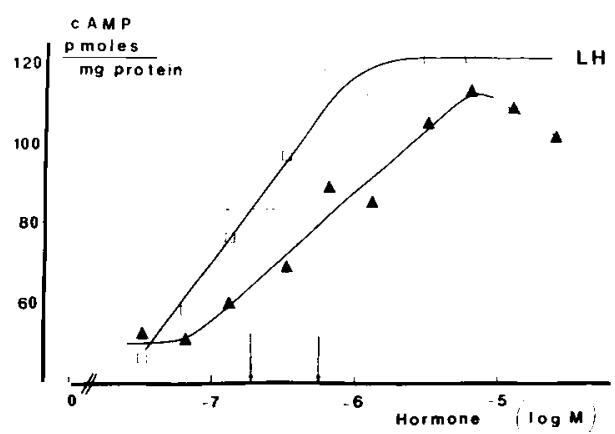

FIG. 6.

FIG. 5. - Activation of rat ovarian adenylate cyclase by $L H$ and benzylated $L H$. Incubation was achieved in conditions similar to those of figure $1 . A_{50}$ values are $4.0 \times 10^{-7} \mathrm{M}$ and $1.3 \times 10^{-6} \mathrm{M}$, respectively.

FIG. 6. - Activation of rat ovarian adenylate cyclase by $\mathrm{LH}$ and pyridy/methyl $\mathrm{LH}$.

$A_{50}$ values are $2.1 \times 10^{-7} \mathrm{M}$ and $7.5 \times 10^{-7} \mathrm{M}$, respectively. 


\section{Discussion.}

The comparaison between the values observed for the three parameters indicated above is summarized in table 2 . The response of juvenile rat ovarian adenylate cyclase to $\mathrm{LH}$ is observed in the same zone of concentration as that reported by other authors (Fonfaine et al., 1973 ; Mason ef al., 1973). Data concerning methyl LH were previously reported elswhere (Tertrin-Clary and De la Llosa, 1975). As can be seen, the maximal activation of ovarian adenylate cyclase induced by the alkylated derivatives seems to decrease with the length of the alkyl chain introduced. The fact that this effect is not so evident in the case of benzyl and pyridylmethyl derivatives may be explained by the degree of alkylation of these derivatives which was lower (50 p. 100) than for the other modified hormones (60-80 p. 100).

TABLE 2

Some characteristics of rat ovarian adenylate cyclase stimulation by different $L H$ derivatives obtained by lysine residue modification

\begin{tabular}{|c|c|c|c|c|c|}
\hline Derivatives & $\begin{array}{l}\text { Maximal } \\
\text { activa- } \\
\text { tion }\left(^{a}\right)\end{array}$ & $\frac{A_{50} \mathrm{LH}}{A_{50} \text { derivative }(b)}$ & $\begin{array}{c}\text { Relative } \\
\text { potency (c) }\end{array}$ & $\begin{array}{c}\text { Relative } \\
\text { potency } \\
\text { OAAD test }\left({ }^{d}\right)\end{array}$ & $\begin{array}{l}\text { Binding } \\
\text { activity } \\
\text { (corpora } \\
\text { lutea) ( }(\text { ) }\end{array}$ \\
\hline $\begin{array}{l}\text { Methyl-LH } \ldots \ldots \ldots \ldots \\
\text { Ethyl-LH } \ldots \ldots \ldots \ldots \ldots \\
\text { Propyl-LH } \ldots \ldots \ldots \ldots \\
\text { Isopropyl-LH } \ldots \ldots \ldots \ldots \\
\text { Benzyl-LH } \ldots \ldots \ldots \ldots \\
\text { Pyridylmethyl-LH } \ldots \ldots \ldots \\
\text { Guanidinated LH ..... } \\
\text { Carbamylated LH..... }\end{array}$ & $\begin{array}{l}1.5 \\
0.85 \\
0.70 \\
0.70 \\
0.90 \\
0.90 \\
0.40 \\
-\end{array}$ & $\begin{array}{l}0.83 \\
0.83 \\
0.63 \\
0.83 \\
0.31 \\
0.33 \\
0.63 \\
-\end{array}$ & $\begin{array}{l}2.1 \\
0.3 \\
0.3 \\
0.4 \\
0.2 \\
0.2 \\
0.2 \\
0.01\end{array}$ & $\begin{array}{l}1.43(1.01-2.02) \\
0.35(0.20-0.60) \\
0.08(0.04-0.18)\end{array}$ & $\begin{array}{l}0.97 \\
0.25 \\
0.16\end{array}$ \\
\hline
\end{tabular}

(a) In terms of maximal activation produced by native LH.

(b) $\mathrm{A}_{50}=$ concentration needed to obtain half-maximal activation.

(c) Resulting from comparison of the concentrations needed for obtaining the cAMP production observed in half-maximal activation by native LH.

( $\left.{ }^{d}\right)$ De la Llosa ef al. (1974).

(e) De la Llosa-Hermier et al. (1977).

In the radioligand receptor assay, the affinity of the ethylated and isopropylated derivatives for different receptors appears to be significantly lower than that of native $\mathrm{LH}$ (De la Llosa-Hermier et al., 1977). The introduction of C-2 or C-3 chains into the amino-groups seems sufficient to diminish the affinity of the hormones for the receptors. Nothing similar is observed concerning the value of the concentration necessary for half-maximal stimulation $\left(A_{50}\right)$ of ovarian adenylate cyclase. These data were established using different biological material which may explain the apparent discrepancies. We are now investigating whether similar resulrs may be obtained using the same biological material for the two tests (Leydig cells). In any case, we think that if these facts and these discrepancies are confirmed there will be no contradictions in the data. Interaction of the hormone with the receptors and interaction of 
the hormone-receptor complex with the adenylate cyclase could constitue two different subsequent events in the $\mathrm{LH}$ action mechanism as it is conceived in the mobile receptor hypothesis (Cuatrecasas and Hollenberg, 1976). The " apparent affinities » of the hormone for the receptor and for the adenylate cyclase system would then appear to be altered to a different degree by the same chemical modification.

The introduction of groups of greater molecular size (benzyl, pyridymethyl), however, leads to a significant change in the $A_{50}$ value, suggesting a decrease of the "apparent affinity » of these derivatives for the enzyme system. This is probably due to steric hindrance and/or to distortion of the molecular conformation of the hormone. The similar pattern of the dose response curves of these two different derivatives suggests, on the other hand, that the presence of a basic group in position 4 of the cycle does not seriously alter the biological properties of the derivatives.

The guanidinated derivative appears to be less active than native $\mathrm{LH}$, but it exhibits significant activity even when guanidination is almost quantitative. Liu et al. (1975) reported, however, that a completely guanidinated LH was practically inactive in the radioligand receptor assay (rat testis homogenate) as well as in the ovarian ascorbic acid depletion test ( 0.03 and 0.04 in terms of native $\mathrm{LH})$. We must therefore compare the action of these derivatives on the same biological material at different levels.

The results reported in the present work confirm the general conclusions previously reached using other bioassays and concerning the relationships between chemical structure and biological activity. It appears, however, that the effect on biological activity caused by these modifications can be quantitatively different when different criteria are used to measure derivative potency : cAMP accumulation in the rat ovary, receptor binding or ovarian ascorbic acid depletion in vivo.

Further investigation will be necessary to determine if these differences are due to the different nature of the target organ or to a non-strict correlation between the three phenomena.

Reçu en mai 1978.

Accepté en juillet 1978.

Acknlowledgements. - We acknowledge the help of Dr Jutisz who kindly provided the ovine $\mathrm{LH}$ and of $\mathrm{Mr}$ Poissonnier who prepared it. This work was supported in part by the Délégation à la Recherche Scientifique et Technique, Contrat no 74-70580.

Résumé. La stimulation de l'adényclase ovarienne de ratte prépubère par différents dérivés de la lutropine (hormone lutéinisante, $L H$ ) a été étudiée. Ces dérivés ont été préparés par modifications chimiques des résidus de lysine de la LH. La LH carbamylée est inacłive mais les dérivés dans lesquels la charge positive des groupes aminés est préservée sont actifs. Dans le cas des dérivés alkylés, la capacité de stimuler l'adénylcyclase diminue lorsque la longueur de la chaîne alkylée augmente. Dans le cas des dérivés ethylé et isopropylé, seule l'activation maximale est diminuée sans changement significatif de la concentration nécessaire pour obtenir la moitié de la stimulation maximale $\left(A_{50}\right)$. La LH guanidylée (dont 95 p. 100 des résidus de lysine sont modifiés) est toujours active. 


\section{References}

CuAtrecasas P., HOLLenberg M. D., 1976. Membranes receptors and hormone action. Adv. Protein Chem., 30, 251-451.

DE LA LLOSA P., 1968. Structure-activity relationships of protein and polypeptide hormone-Gonadotropins. Excerpfa med. ICS Ser., no 161, part II, 1-2.

DE LA LLOSA P., DUROSAY M., TERTRIN-CLARY C., JUTISZ M., 1974. Chemical modification of lysine residues in ovine luteinizing hormone. Effect on biological activity. Biochim. biophys. Acta, 342, 97-104.

DE LA LLOSA-HERMIER M. P., DE LA LLOSA P., HERMIER C., 1977. Studies of the binding activity to different gonadal receptors of ovine luteinizing hormone (LH) after chemical modification of lysine residues. Gen. comp. Endocrinol., 31, 302-306.

FONTAINE Y. A., SALMON C., FONTAINE-BERTRAND E., DELERUE-LE BELLE N., 1973. Age-related changes in FSH and $\mathrm{LH}$-sensitive ovarian adenyl cyclase from prepubertal rats. Horm. Metab. Res., 5, 376-380.

GILMAN A. G., 1970. A protein bindind assay for adenosine 3'-5'-cyclic monophosphate. Proc. nat. Acad. Sci. US., 67, 305-312.

LIU W. K., YANG K. P., NAKAGAWAY., WARD D. N., 1974. The role of the amino group in subunit association and receptor site interaction for ovine luteinizing hormone as studied by acylation. J. biol. Chem., 249, 5544-5550.

LIU W. K., ESFAHANI M., WARD D. N., 1975. Guanidination of ovine luteinizing hormone and effects on activity. Endocr. Res. Commun., 2, 47-63.

LIU W. K., WARD D. N., 1975. Preparation of lutropin with acetyl or acetimidinyl substituents on the amino groups of the $\beta$-subunit. Biochim. biophys. Acta, 405, 522-526.

LOWRY O. H., ROSENBROUGH N. J., FARR A. L., RANDALL R. J., 1951. Protein measurement with the Folin phenol reagent. J. biol. Chem., 193, 265-275.

MASON N. R., SCHAFFER R. J., TOOMEY R., 1973. Stimulation of cyclic AMP in rats ovaries in vitro. Endocrinology, 93, 34-41.

MASON N. R., MARSH R., 1975. The effect of LH on cyclic AMP and progesterone in rat ovaries in vivo. Endocr. Res. Commun., 2, 167-177.

MEANS G. E., FEENEY R. E., 1968. Reductive alkylation of aminogroups in proteins. Biochemistry, 7, 2192-2201.

PARLOW A. F., 1961. Bioassay of pituitary luteinizing hormone by depletion of ovarian ascorbic acid, 300-310. In ALBERT A., Human pituitary gonadotropins, Thomas, Springfield (III).

SAIRAM M. R., LI C. H., 1975. Reaction of ovine interstitial cell stimulating hormone with citraconic and maleic anhydrides. Arch. Biochem. Biophys., 167, 534-539.

TERTRIN-CLARY C., DE LA LLOSA P., 1975. Stimulation de l'adényl cyclase ovarienne de ratte par l'hormone lutéinisante (LH) méthylée. Influence de l'acide éthylène-diamino-tétraacétique. C. R. Acad. Sci. Paris, Série D, 281, 823-826. 